\title{
Analisis Simbolik Kyrie Eleison Karya Anna Wahyu Prasetyowati
}

\author{
RINA MARTIARA DAN ANISA FEBRIANA ${ }^{1}$ \\ Jurusan Seni Tari, Fakultas Seni Pertunjukan, Institut Seni Indonesia Yogyakarta
}

\begin{abstract}
Symbolic Analysis of Kyrie Eleison of Anna Wahyu Prasetyowati's Work. This paper describes and interprets the Kyrie Eleison as a performing arts. Kyrie Eleison text is read through choreography elements that shape the themes, motion, musical accompaniment, fashion makeup, floor pattern, form and stage layout. This paper uses hermeneutic approach. Based on the research it can be concluded that this work has a deep meaning. The story of Jesus Christ journey in teaching the word with great passion until his death on the Cross is fixated religious values that serve as an example for mankind. This work also contains the values of humanity that every human being must be having a miserable, suffering, and death. Humans must be steadfast and strong in the face of every temptation that comes when he/she want to achieve the highest inner awareness and understanding of divine truth.
\end{abstract}

Key Words: walk by the cross, kyrie eleison, choreography.

\section{Pendahuluan}

Secara konseptual Kyrie Eleison menggambarkan sengsara dan derita perjalanan dan wafat Yesus di kayu salib sebagai jalan untuk menebus dosadosa umat manusia. Dalam kepercayaan umat Katolik, terdapat suatu tradisi religius berupa prosesi untuk mengenang dan merenungkan kisah sengsara Yesus yang disebut dengan Jalan Salib. Jalan Salib berasal dari bahasa Latin 'via crusis' atau 'via dolorosa' yaitu jalan penderitaan yang merujuk pada penggambaran masa-masa terakhir penderitaan Yesus dan diperingati sebagai devosi yang umumnya dilakukan umat Katolik pada saat pra Paskah atau pada hari Jumat Agung. Devosi merupakan salah satu bentuk doa yang berlaku dalam tata cara gereja Katolik yang bernada pribadi untuk memperpanjang renungan pribadi atas suatu misteri keselamatan.

Kisah perjalanan Yesus yang penuh derita mulai dari benteng Antonia sampai bukit Golgota ini memiliki empat belas perhentian, yaitu: Perhentian I: Yesus Dihukum Mati; Perhentian II: Yesus Memanggul Salib; Perhentian III: Yesus Jatuh Pertama Kalinya; Perhentian IV: Yesus Berjumpa dengan Ibunya; Perhentian V: Yesus Ditolong Simon dari Kirene; Perhentian VI: Veronika Mengusapi Wajah Yesus; Perhentian VII: Yesus Jatuh Kedua Kalinya; Perhentian VIII:
Yesus Menasehati Wanita-Wanita yang Menangis; Perhentian IX: Yesus Jatuh Ketiga Kalinya; Perhentian X: Pakaian Yesus Ditanggalkan; Perhentian XI: Yesus Dipaku di Kayu Salib; Perhentian XII: Yesus Wafat di Salib; Perhentian XIII: Yesus Diturunkan dari Salib; dan Perhentian XIV: Yesus Dimakamkan.

Perjalanan Yesus yang tersirat melalui Jalan Salib merupakan suatu paradigma bagi perjalanan hidup umat manusia di mana sengsara, derita, dan kematian itu benar-benar ada dan nyata. Setidaknya hal itulah yang ingin disampaikan koreografer melalui karya tari Kyrie Eleison. Dalam konteks moral kepercayaan, gereja selalu memandang atau menilai seni itu indah, apabila selaras dengan iman, ketaqwaan, dan hukum keagamaan, serta cocok digunakan dalam ibadat untuk mengungkapkan puji syukur serta kemuliaan-Nya (Hadi, 2006: 265). Pertunjukan tari juga dapat dipergunakan sebagai sarana pewartaan ajaran agama Katolik, lewat ceritacerita dalam Kitab Perjanjian Lama maupun Perjanjian Baru yang diungkapkan dengan gerak tari (Widyasmoro, 2004).

Sebagai tugas akhir karya yang dipentaskan di panggung proscenium Jurusan Tari Fakultas Seni Pertunjukan Institut Seni Indonesia Yogyakarta pada hari Minggu, 18 Januari 2009 bersamaan

1 Alamat korespondensi: Prodi Tari ISI Yogyakarta. Jalan Parangtritis Km. 6,5 Sewon, Yogyakarta 55188. E-mail: martiararina@yahoo.com 
dengan sembilan karya dari sembilan orang koreografer muda yang lain, Kyrie Eleison tampil dengan ciri dan karakteristik yang menonjol dan memiliki unsur-unsur seperti yang dikemukakan Monroe Beardsley. Karya ini masuk dalam tiga besar karya terbapenafsiran penonton yang memiliki interpretasi yang berbeda-beda dengan maksud sesungguhnya yang ingin disampaikan koreografer melalui simbol gerak dalam Kyrie Eleison? Untuk menjawab pertanyaan ini, penulis menggunakan pendekatan hermeneutika. Tugas hermeneutika adalah menafsirkan makna dan pesan seobjektif mungkin sesuai dengan yang diinginkan teks. The Liang Gie (1997: 49) berpendapat bahwa keindahan atau ciri-ciri yang menciptakan nilai estetis adalah sifat yang memang telah melekat pada benda indah (kaitannya dengan karya tari) yang bersangkutan, terlepas dari orang yang mengamatinya. Teks itu sendiri tentu saja tidak terbatas pada fakta otonom yang tertulis atau terlukis, tetapi selalu berkaitan dengan konteks. Di dalam konteks terdapat berbagai aspek yang bisa mendukung keutuhan pemaknaan. Aspek yang dimaksud menyangkut juga biografi kreator atau seniman dan berbagai hal yang berkaitan dengannya. Hal yang harus diperhatikan adalah seleksi atas hal-hal di luar teks harus selalu berada dalam petunjuk teks. Ini berarti bahwa analisis harus selalu bergerak dari teks, bukan sebaliknya. Hal terpenting dari semua itu adalah bahwa proses penafsiran selalu merupakan dialog antara teks dan penafsir (Saidi, 2008: 377).

Peneliti berusaha menafsirkan simbol-simbol yang terdapat pada koreografi Kyrie Eleison sesuai interpretasi yang didukung dengan data-data faktual yang diperoleh dari beberapa narasumber termasuk koreografer, sebagai salah satu cara menjembatani interpretasi si pencipta karya dengan penikmat karyanya. Memang bukan suatu hal yang mudah dalam menafsirkan simbol-simbol gerak dalam koreografi Kyrie Eleison, terlebih lagi terdapat perbedaan keyakinan religi yang melatarbelakangi antara peneliti yang seorang Muslim dengan objek koreografi Kyrie Eleison yang sarat akan budaya liturgi Gereja Katolik. Tanpa bermaksud memperbandingkan atau menyinggung permasalahan SARA, penelitian ini merupakan suatu pembelajaran sudut pandang untuk mendewasakan pemikiran peneliti dalam menilai suatu hal.

\section{Jalan Salib Sebagai Devosi}

Jalan Salib sebagai tema universal dalam karya Kyrie Eleison pada dasarnya merupakan salah satu devosi yang diakui dan diyakini dalam kepercayaan umat Katolik. Doa Rosario, Adorasi Ekaristi, berbagai penghormatan kepada Santa Maria, Hati Kudus Yesus merupakan contoh devosi yang tetap ada hingga sekarang. Semua kegiatan saleh ini dilaksanakan karena terdorong oleh sikap iman. Jalan salib sebagai sebuah devosi dan pertunjukan juga pernah dibuat oleh Darmawan Dadiono (2008: 65-72) dalam bentuk komposisi tari yang dipentaskan di gua Tritis, Wonosari.

Devosi tumbuh sejak abad ke-7. Ketika bahasa Latin ditetapkan sebagai bahasa liturgi yakni ibadat resmi yang ditetapkan oleh otoritas gereja. Dengan bahasa Latin sebagai bahasa liturgi, maka kebanyakan umat tidak cukup mengerti lagi tentang liturgi. Untuk itu dicari bentuk doa yang lebih dipahami dan mudah dihayati serta lebih bersifat personal yang di dalamnya ikut serta juga paham teologis (Sembiring, 2007). Pada umumnya devosi itu lahir untuk memperpanjang renungan pribadi atas sesuatu misteri keselamatan. Melalui devosi dinyatakan sikap hormat dan hubungan khusus antara umat beriman dengan pribadi Ilahi, Santa Maria, dan dengan para kudus di dalam gereja.

Devosi sebagai doa pribadi merupakan tuangan dari kegelisahan masyarakat atas situasi kehidupan yang dirasakan dengan bercermin pada situasi yang pernah dialami Yesus atau Bunda Maria semasa hidupnya. Sebagai contoh, Doa Rosario sebagai renungan yang merupakan 'ringkasan Injil', karena di dalamnya dirangkai dan direnungkan sejarah keselamatan yang dipaparkan dalam Injil, mulai kisah-kisah sekitar inkarnasi sampai dengan kebangkitan dan kenaikan Tuhan. Dengan ditambahkannya satu rangkaian peristiwa baru, yakni peristiwa terang, doa Rosario menjadi ringkasan Injil yang lebih utuh. Kini renungan Rosario mencakup peristiwa-peristiwa sekitar inkarnasi dan masa kecil Yesus, peristiwa-peristiwa amat penting dalam pelayanan Yesus di hadapan umum, peristiwa-peristiwa sekitar sengsara-Nya, dan kenangan akan kebangkitan-Nya. Sambil mendaraskan doa Salam Maria berulang-ulang, para pendoa merenungkan salah satu misteri yang dirangkai dalam rosario.

Devosi itu didukung sungguh oleh Gereja asalkan selaras dengan iman resmi Katolik. Injil 
Mateus 6: 6 misalnya jelas mengungkapkan bagaimana doa pribadi harus dilaksanakan, "Jika engkau berdoa, masuklah ke dalam kamarmu, tutuplah pintu dan berdoalah kepada Bapamu yang ada di teepat tersembunyi”. Devosi sebagai doa pribadi tentu mengakar pada ide ayat ini. Hal yang paling penting dipegang ialah devosi itu adalah bentuk doa sebagaimana juga liturgi adalah bentuk doa. Kedua bentuk doa ini samasama mengungkapkan iman dan kebaktian khas Katolik. Hanya saja devosi itu lahir dari inisiatif pribadi yang kemudian diakui oleh gereja tetapi tidak menjadi doa resmi yang mengikat. Dengan demikian devosi itu memiliki bentuk bebas, dapat dirombak sesuai dengan kebutuhan orang atau selera daerah.

Akan tetapi devosi yang terlalu menonjolkan unsur subyektif dapat mengaburkan kesatuan iman pribadi dalam kebersamaan iman gerejani. Bila devosi terlalu banyak dikuasai oleh emosi dan afeksi bisa saja devosi menjerumuskan orang ke tindakan berbau tahayul dan magis. Oleh karena itu almarhum Paus Yohanes Paulus II dalam surat apostoliknya mengingatkan,

Devosi-devosi itu perlu terus menerus diinjili, sehingga iman yang diungkapkan di dalamnya dapat menjadi tindakan yang semakin matang dan benar. Devosi yang merakyat ini tidak boleh diabaikan atau diperlakukan dengan acuh tak acuh atau malah diremehkan, karena devosidevosi itu kaya akan nilai, dan kegiatan itu sendiri mengungkapkan sikap religius terhadap Allah (Sembiring, 2007).

Paus Yohanes Paulus II ini amat yakin devosi dan liturgi sama-sama mengembangkan kehidupan rohani dan memperdalam iman umat. Situasi kehidupan masyarakat abad pertengahan yang ditandai oleh kemiskinan ekonomi dirasakan sangat berat dan begitu penuh penderitaan pada saat itu. Dari situlah muncul kesadaran betapa pentingnya mengenang sengsara Kristus, sebagai salah satu cerminan betapa manusia harus mengalami berbagai macam ujian hidup melalui kesengsaraan untuk mencapai kesenangan. Kilas balik kisah sengsara ini sekaligus menjadi bahan renungan abadi yang selalu relevan sepanjang masa dan tidak lekang dimakan waktu, serta sejalan dengan makna introspeksi atas semua tindakan yang pernah dilakukan guna mencari kebenaran tertinggi yakni "Kebenaran Ilahi”.
Ziarah ke situs kelahiran dan wafatnya Yesus Kristus sebagai jalan kilas balik kisah dan sengsara-Nya telah dimulai sejak abad pertama. Ziarah terkenal pertama dilakukan oleh Santa Helena, ibunda Raja Konstantin pada abad ke-4. Santa Helena melakukan ziarah untuk mengenal dari dekat situs-situs kelahiran, wafat dan dimakamkannya Yesus Kristus. Sejak Yerusalem dikuasai oleh kaum Muslim, ziarah ke Tanah Suci ini menjadi tindakan yang sangat berbahaya karena nyawalah taruhannya.

Tempat Tanah Suci ini direbut kembali oleh tentara-tentara Perang Salib pada tahun 1199 sehingga ziarah dapat dilakukan dengan aman dan damai. Sayangnya hal ini tidak berlangsung lama karena pada tahun 1291 tanah ini kembali dikuasai oleh kaum Muslim. Setelah itu ziarah menjadi berbahaya lagi.

Pada abad 20 ini terjadi Zionisme dari bangsa Israel yang ingin kembali ke tanah pusaka mereka. Dan memang aksi ini menjadi aksi berdarah. Beruntunglah bahwa tampil tokohtokoh perdamaian sehingga dapat meredam aksi berdarah dari aksi Zionisme ini. Di masa tenang, terjadi rekonsiliasi 3 agama besar, yaitu Islam, Yahudi dan Kristen tentang Tanah Suci Yerusalem dan sekitarnya sehingga para peziarah dari ketiga agama ini dapat melakukan ziarah dengan aman. Dan memang sudah seharusnyalah kedamaian ini dapat tercipta.

Fransiskus dari Asisi adalah yang pertama kali mempopulerkan Jalan Salib bersama dengan rahib-rahib Fransiskan pada abad ke-14. Devosi ini kemudian merebak ke setiap gereja dengan membuat pemberhentian-pemberhentian kecil di dalam gereja. Kini perhentian-perhentian Jalan Salib ini sudah banyak diterapkan juga dalam areal yang luas di luar gereja, misalnya Gua Sendang Sono di Muntilan atau Gua Kerep di Ambarawa dan masih banyak lagi. Para rahib Fransiskan juga menciptakan lirik Stabat Mater yang sampai kini selalu dinyanyikan untuk mengiringi upacara Jalan Salib. Lirik ini telah tersebar dan diterjemahkan ke berbagai bahasa. Kemudian Paus Clement XII (1730-1740) menetapkan empat belas pemberhentian pada Jalan Salib. Dan keempat belas pemberhentian inilah yang sampai kini diterapkan oleh Umat Katolik. 


\section{Deskripsi Pertunjukan Kyrie Eleison}

Sejak awal, lampu proscenium pada bagian penonton yang memang dimatikan semakin terasa sakral ketika intro iringan Kyrie Eleison dimainkan. Intro Kyrie Eleison berupa ilustrasi lolongan dan lengkingan suara-suara jeritan manusia. Kemudian muncul penari di pojok depan kiri penonton yang berkostum jubah hitam, dengan gerak yang disertai mimik wajah mencekam. Bergantian dengan dua orang penari yang duduk di atas tangga pojok belakang bagian kanan penonton dengan gerak-gerak tangan yang menunjukkan gambaran berdoa, memohon sesuatu dari 'atas'. Pada adegan ini terdengar senandung 'Kyrie... Eleison' dari seorang penyanyi putra. Hal ini seolah memberi kesan tragedi dramatik pada penonton. Tata panggung yang menggunakan tiga buah tangga trap, kemudian diletakkannya sebuah pohon kering menjelaskan bahwa karya ini merupakan penggambaran dari suatu kejadian yang berlangsung di suatu tempat. Iringan yang didukung dengan live paduan suara berkostum jubah putih dengan membawa lilin memang diarahkan menggiring penonton pada interpretasi yang berkaitan dengan suasana liturgi dalam gereja.

Tujuh orang penari putri yang berkostum serba kembar dan serba hitam muncul bersamaan. Satu penari dari arah kanan, satu penari dari kiri, dua penari dari depan, dan tiga orang penari dari belakang panggung dengan menuruni anak tangga, kemudian berpotongan membentuk pola lantai salib di tengah-tengah panggung. Ketujuh penari bergerak rampak seiring dengan musik yang temponya semakin cepat. Para penyanyi membentuk harmonisasi dengan lirik yang minimalis seperti "ha.ha.ha....ho.ho.ho....”. Motif gerak yang menonjol pada adegan ini adalah rentangan tangan, gerak kepala, gerak menutup muka dengan kain hitam, kemudian jatuh terlentang dan melakukan gerak-gerak dalam level bawah.

Adegan selanjutnya membentuk pola lantai lingkaran, dengan menampilkan variasi gerak, dan komposisi selang-seling atau cannon. Tampak tiga penari bergerak dengan tempo yang konstan, sedangkan empat penari lain improvisasi saling menggendong. Kemudian gerak kembali rampak, tujuh penari meng-eksplore kain hitam dan membentuk pola lantai setengah lingkaran.
Ketujuh penari kemudian berpindah membentuk pola lantai salib menyudut ke bagian kiri panggung. Gerak yang ditampilkan rampak berlevel bawah seperti jongkok atau berlutut disertai rentangan tangan yang luas. Pada adegan ini musik tidak begitu terdengar, yang ditonjolkan adalah paduan suara yang berseru 'Eleison' saling bersaut-sautan. Ketika paduan suara berhenti, musik kembali terdengar dengan frekuensi cukup keras. Para penari membentuk pola lantai Salib dengan memanfaatkan level dari anak tangga sebanyak dua kali, anak tangga pojok kanan dan kiri dengan gerak transisi berjalan dan berputar, kemudian kembali membentuk Salib di tengah panggung.

Adegan selanjutnya memperlihatkan tiga orang dengan level berdiri, bergerak pelan dengan mengolah kain hitam yang dikerudungkan. Sedang empat penari lain hanya berpose dengan mengangkat satu tangan lurus ke arah tiga penari utama. Kemudian pola lantai berubah menjadi 3-3-1, tiga penari di pojok belakang kanan, tiga di pojok belakang kiri, dan seorang penari di tengah. Pada bagian ini motif-motif gerak yang digunakan pada bagian awal dimunculkan kembali. Keenam penari yang semula di belakang kemudian membentuk lingkaran mengelilingi seorang penari yang di depan. Enam penari berputar seperti terbang dengan menggunakan sayap kain hitam perlahan mengelilingi seorang penari yang borpose berlutut tertutup kain hitam. Lingkaran mulai terbuka dan membentuk pola dengan bantuan level dari anak tangga. Penari merentangkan kostum hitamnya sepanjang rentangan tangan menyerupai bentuk burung terbang.

Pola kembali ke bentuk lingkaran. Enam penari tidur terlentang mengelilingi seorang penari yang tadinya berlutut kemudian bangkit, bergerak mengolah kostum hitamnya yang panjang. Dengan gerak berputar sebagai transisi, pola berganti. Empat penari membentuk pola lilin di samping kanan dan kiri, seorang penari tidur terlentang dan seorang lagi duduk di depan kepala penari yang terlentang, melingkup memeluk lututnya. Sedang tiga penari lain melambangkan seseorang yang sedang disalib. Dua penari berdiri sejajar membentuk salib dengan tangannya, dan seorang penari berdiri tertunduk di depan Salib. 
Adegan dilanjutkan dengan pola dan gerak acak meng-eksplore kain kostum hitam. Di bagian ini dinamika musik kembali naik. Kemudian penari berjajar dengan gerak improvisasi melepas kostum hitam berganti ke kostum putih, seiring penambahan efek asap buatan. Berputar-putar sebagai transisi hingga akhirnya penari jatuh di tengah panggung dengan membentuk pola lantai Salib. Musik berhenti dan lampu padam. Yang tampak hanya bentuk Salib putih yang berkilauan keunguan akibat lampu ultra violet.

Di sinilah terdengar riuh tepuk tangan penonton yang menandakan bahwa penonton baru saja menyaksikan pertunjukan yang dinilai bagus. Akan tetapi pertunjukan belum selesai. Seorang penyanyi wanita bersenandung "Kyrie...Eleison..." dengan suara sopran yang melengking. Seiring bunyi musik yang menggema, dari atas panggung turun beberapa helai kain putih. Para penari bergerak perlahan. Lima orang penari meraih kain, meng-eksplore-nya kemudian melilitkan kain putih itu ke tubuhnya. Seorang penari paling depan tengkurap dengan mimik wajah tersiksa kesakitan, dan seorang lagi berimprovisasi dengan menguraikan rambutnya yang panjang, bergerak seolah menggambarkan kegundahan dan amarah, kemudian mengerudungkan kain putih di atas kepalanya. Penari yang berkerudung kemudian menghampiri penari yang kesakitan, menolongnya dan membantunya berdiri.

Penari membentuk properti kain putih yang diturunkan dari atas menjadi bentuk Salib, dengan dua orang penari terlilit kain di bagian tengah, memperlihatkan seorang penari berkerudung memangku seorang penari. Setelah gerak dan musik berhenti, tampak rentangan kain putih yang lebar di atas penonton, membentang dari arah depan penonton ke belakang, kemudian kain itu sobek dan bunga mawar putih berguguran. Pertunjukan yang malam itu sebagai penampilan pertama, mendapat respons tepuk tangan penonton yang bergemuruh disertai dengan teriakan atau bahkan siulan yang menunjukkan bahwa pertunjukan itu mampu membuat penonton terkesan.

\section{Analisis Simbolik Kyrie Eleison}

Tema dapat dipahami sebagai isi yaitu pokok permasalahan yang terkandung dalam sebuah koreografi baik itu bersifat literal maupun non literal (Hadi, 2003:89). Karya Kyrie Eleison yang mengangkat tema Jalan Salib ini memiliki esensi yang mendalam, di mana kisah sengsara perjalanan Yesus dari benteng Antonia ke Bukit Golgota yang memiliki empat belas perhentian seperti telah dijelaskan di depan. Dalam koreografi ini ditambahkan lagi dengan satu perhentian lagi yaitu Perhentian XV: Yesus Bangkit dan Naik Ke Surga. Penambahan perhentian ini tidak dilakukan sembarangan, tetapi harus relevan dengan alur cerita Jalan Salib. Kejadian Yesus bangkit setelah dimakamkan memang disebutkan dalam beberapa ayat di Al Kitab.

Menjelang menyingsingnya fajar pada hari pertama minggu itu, pergilah Maria Magdalena dan Maria yang lain menengok kubur Yesus. Maka terjadilah gempa bumi yang hebat, sebab seorang malaikat Tuhan turun dari langit dan datang ke batu itu dan menggulingkannya lalu duduk di atasnya. Malaikat itu berkata "Janganlah kamu takut, sebab aku tahu kamu mencari Yesus yang disalibkan itu. Ia tidak ada di sini, sebab Ia telah bangkit, sama seperti yang telah dikatakanNya" (Mat. 28:1-6).

Yaitu bahwa anak manusia harus diserahkan ke tangan orang-orang berdosa dan disalibkan, dan akan bangkit pada hari yang ketiga (Luk. 24:7).

Yesus menampakkan diri kepada semua murid. Ia berkata kepada mereka "Inilah perkataanKu yang telah Kukatakan kepadamu ketika Aku masih bersama-sama dengan kamu. Dan Aku akan mengirim kepadamu apa yang dijanjikan BapaKu". Ia mengangkat tangan-Nya dan memberkati mereka. Dan ketika Ia sedang memberkati mereka, Ia berpisah dari mereka dan terangkat ke sorga. (Luk24:51)

Perhentian-perhentian ini merupakan adeganadegan yang dibuat oleh koreografer untuk menjabarkan tema koreografi, untuk kemudian koreografer menggunakan simbol-simbol gerak sebagai sebuah media pengungkapan agar makna Jalan Salib tersampaikan kepada penonton, meski dalam proses penyusunan alur ceritanya beberapa perhentian digabung menjadi satu adegan agar tidak terlalu panjang dan terkesan berulang-ulang.

Kisah sengsara Yesus dalam Injil menjadi sumber bagi sebagian besar dari keempatbelas perhentian Jalan Salib. Peristiwa Yesus dijatuhi hukuman mati oleh Pilatus, Yesus memanggul salib-Nya, Simon dari Kirene membantu memanggul salib, perempuan-perempuan yang menangisi-Nya, pakaian Yesus ditanggalkan, Yesus disalibkan, Yesus wafat, Yesus diturunkan dari 
salib dan dimakamkan, semuanya dicatat dalam Kitab Suci. Akan tetapi bagaimana dengan peristiwa-peristiwa yang tidak disebutkan dalam Injil? Misalnya peristiwa Yesus berjumpa dengan Maria, Bunda-Nya; Veronica mengusap wajah Yesus; Yesus jatuh sebanyak tiga kali; dari manakah kisah-kisah ini berasal? Tampaknya kisah-kisah tersebut berasal dari para peziarah perdana yang mengunjungi Yerusalem.

Menurut Injil Yohanes, Bunda Maria berdiri di dekat Salib Yesus (Yoh 19:25-27). Tidakkah Bunda Maria termasuk dalam rombongan yang mengikuti-Nya dalam perjalanan-Nya ke Kalvari, tempat Yesus disalibkan, dan tidak mungkinkah mereka bertemu dalam perjalanan itu? Para peziarah yang napak tilas di sepanjang Via Dolorosa (jalan sengsara) yakin akan hal tersebut.

Yesus tentulah teramat lelah dan lemah selama sengsara-Nya. Jika tidak demikian, mengapakah Simon dari Kirene dipaksa untuk membantu memanggul salib-Nya? Bukankah penderaan yang dilakukan oleh para prajurit Pilatus demikian dahsyatnya? Para peziarah yang melewati Via Dolorosa menyimpulkan bahwa Yesus jatuh lebih dari satu kali oleh sebab kondisi-Nya yang sedemikian lemah. Sementara para peziarah sendiri menapaki jalan Yerusalem yang sulit serta berlikuliku, mereka yakin bahwa pastilah Yesus jatuh berulang kali.

Kisah Veronica tidak diceriterakan dalam Injil manapun, tetapi dicatat dalam tulisan-tulisan apokrip. Kisah Pilatus dari abad kedua mencatat bahwa seorang wanita bernama Veronica (Bernice, dalam bahasa Yunani) adalah wanita yang sama dengan yang telah disembuhkan Yesus dari sakit pendarahan (Mat 9: 20-22). Wanita itu datang pada saat Yesus diadili di hadapan Pilatus untuk menyatakan bahwa Ia tidak bersalah. Versi sesudahnya yang berasal dari abad keempat atau kelima tercatat bahwa Veronica memiliki sepotong kain dengan gambar wajah Yesus. Para peziarah Barat kembali ke Eropa dan menceritakan kisah tentang Veronica. Oleh karena devosi Jalan Salib berkembang pada akhir abad pertengahan, kisah Veronica dikenangkan dalam perhentian keenam. Veronica mengusap Wajah Yesus dalam perjalananNya ke Kalvari dan Yesus meninggalkan gambar wajah-Nya di kerudung Veronica. Relik dengan gambar wajah Yesus, yang dikenal sebagai "Kerudung Veronica", dihormati di Gereja St.
Petrus di Roma sejak abad VIII.

Yesus sebagai manusia suci sesungguhnya menjalani sengsara-Nya dengan penuh kekuatan, ketegaran, dan keyakinan atas pertolongan Allah. Akan tetapi kesan melankolis justru timbul dari orang-orang disekitar-Nya, orang-orang yang menyaksikan penderitaan Yesus saat disiksa, dan bagaimana perasaan seorang ibu seperti Bunda Maria ketika melihat anaknya diperlakukan seperti itu. Konflik inilah yang dimunculkan dalam alur Kyrie Eleison. Hal ini menjadikan koreografi Kyrie Eleison cenderung dramatik atau lebih bersifat literal dan gerak-geraknya bertipe liris yang mengacu pada kualitas gerak lembut dan memberi kesan suasana puitis. Mode penyajian simbolis representasional bertujuan untuk tidak menimbulkan kejenuhan bagi penonton dan memberikan ruang lebih pada koreografer dalam mengembangkan gerak. Tari memang merupakan suatu sajian gerak-gerak simbolis, tetapi kadangkala sajian itu terdiri dari simbol-simbol gerak yang jelas dapat diidentifikasikan makna atau artinya (Smith, 2003: 90-91).

\section{Analisis Simbolik Gerak Tari}

Tari sebagai sebuah seni komunikatif menggunakan gerak sebagai materinya. Gerak di dalam tari berbeda dengan gerak sehari-hari. Gerak tari telah melalui perombakan atau dipindahkan dari yang wantah dan diubah bentuknya menjadi seni (Hawkins, 2003: 3). Gerak-gerak melalui eksplorasi dan improvisasi merupakan dasar yang utama dalam koreografi Kyrie Eleison. Gerak-gerak bertempo lambat dihadirkan dalam penggambaran suasana sedih dan duka yang mendalam karena sengsara yang dialami Yesus. Seperti pada saat Yesus didera dan disiksa, digambarkan dengan seorang penari yang bersujud sedangkan keenam penari lainnya mengelilingi dengan langkah kecilkecil berjinjit sambil memainkan kain kostum hitam seolah seperti gerak terbang. Gerak-gerak yang bertempo cepat dengan aksen tegas digunakan sebagai pengungkapan kemarahan bercampur rasa sedih yang memuncak dalam kepasrahan Yesus di Kayu Salib dan tidak mampu berbuat apa-apa. Contohnya gerak berputar-putar dengan cepat dan rentangan tangan yang maksimal. Kegembiraan dalam konteks rasa syukur atas wahyu yang diberikan Tuhan kepada umat manusia yaitu kebangkitan Yesus anak Allah yang 
terlahir ke dunia rela wafat di kayu Salib untuk menebus dosa-dosa umat manusia dihadirkan dalam bentuk gerak-gerak yang lincah, seperti lompat dan berguling.

Bentuk adalah wujud, diartikan sebagai hasil dari berbagai elemen tari yaitu gerak, ruang, dan waktu di mana secara bersama-sama elemen-elemen itu mencapai vitalitas estetis (Blom, 2003: 24). Bentuk tidak menunjuk pada bentuk gerakan-gerakan, atau aransemen gerakan (Hawkins, 2003: 126). Bentuk merupakan wujud, struktur yang terdiri atas beberapa elemen-elemen yang ditata (Smith, 1987: 6). Bentuk-bentuk gerak yang diperoleh koreografer selama proses pengejawantahan hingga eksplorasi terangkai dalam motif-motif gerak tari yang saling berkaitan hingga membentuk suatu koreografi yang utuh. Motif gerak utama yang sering dimunculkan adalah gerak tangan penari yang membentuk lambang Salib dengan pengembangan pola ruang melebar ke samping, ke atas atau ke depan, bahkan ke belakang dengan diikuti tolehan kepala dan badan. Hal ini digunakan koreografer sebagai simbol untuk mengingatkan bahwa dalam hidup setiap umat manusia (khususnya dalam kepercayaan Katolik) memiliki Salib masing-masing yang harus dipikul.

Gambaran kepasrahan manusia (Yesus) kepada Allah (sesuai makna "Kyrie Eleison") tampak melalui pola gerak kepala yang menunduk dan kadang menengadah menatap ke atas. Selain itu terdapat pula beberapa gerak simbolik seperti penari menutup muka dengan kain hitam sebagai representasi perhentian VI yaitu Veronica mengusapi wajah Yesus.

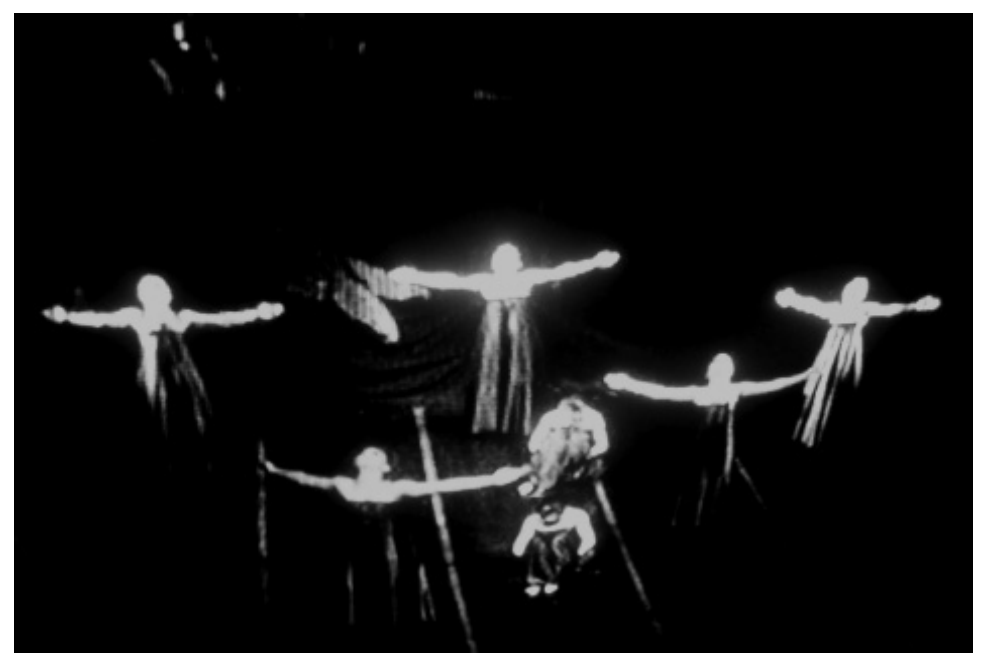

Gambar 1. Lima penari level atas merentangkan tangan dengan kepala mendongak ke atas dan dua penari level bawah menundukkan kepala. (Dokumentasi: DVD pementasan Kyrie Eleison)

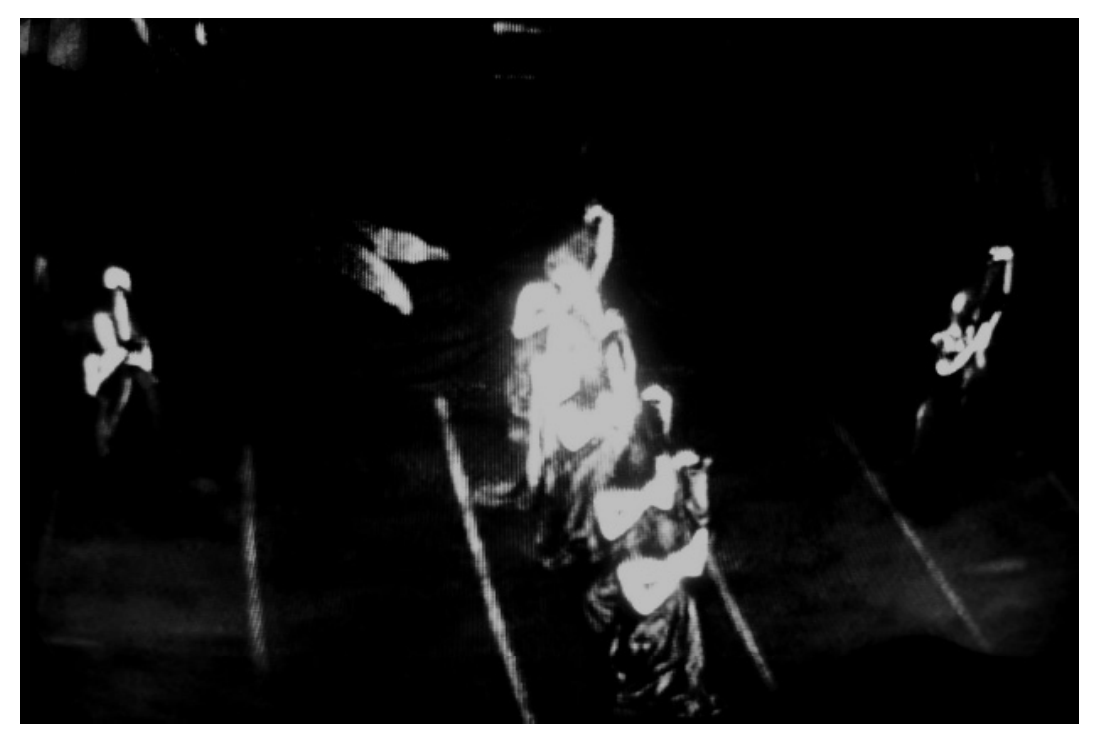

Gambar 2. Simbolisasi Perhentian VI dalam Kyrie Eleison Tujuh penari bergerak rampak menutup muka dengan kain hitam. (Dokumentasi: DVD pementasan Kyrie Eleison) 
Dalam hal ini memang terdapat adanya perbedaan, di mana pada penggambaran asli Jalan Salib, Veronica mengusap wajah Yesus dengan sehelai kain berwarna putih, sedangkan pada Kyrie Eleison wajah penari ditutup dengan kain hitam yang merupakan bagian dari kain kostum. Tampaknya yang lebih ditekankan di sini bukanlah penggambaran perhentiannya, tetapi lebih pada suasana dramatik yang ditonjolkan. Kejadian Veronica mengusap wajah Yesus merupakan sesuatu yang dirasa begitu menyentuh hati, terasa puitis dan melankolis, tetapi terdapat rasa sedih yang mendalam dikarenakan kondisi Yesus yang memanggul salib, disiksa hingga wajah dan sekujur tubuhnya dipenuhi luka, darah, keringat, dan kotoran debu. Maka dari itu penari menggunakan kain berwarna hitam sebagai lambang duka. Warna putih identik dengan lambang suci, dalam konteks ini kesucian kebaikan hati Veronica yang setia melayani Yesus hingga akhir hayatNya.
Dalam pertunjukan Kyrie Eleison yang lebih ditonjolkan adalah empati duka mendalam yang dirasakan Veronica ketika melihat Yesus menderita, lebih ditegaskan lagi dengan ilustrasi iringan yang melankolis. Secara teknis, ideologi seorang penata tari kadang kala mengakibatkan sedikit banyak "pemaksaan" atau penyesuaian antara sumber tema dengan bentuk penyajian karya. Hal ini tentunya sah-sah saja dilakukan, asalkan tetap berada dalam koridor konteks tema cerita dan wujud estetika pertunjukannya.

Selain contoh tersebut, masih banyak simbolsimbol lain dalam Kyrie Eleison yang memberi keleluasaan untuk menginterpretasi. Bentuk penyajian Kyrie Eleison yang dipetakan Anna dalam Kyrie Eleison sebagai berikut:

Adegan I: introduksi dengan vocal untuk menciptakan suasana hening dan dramatik.

Adegan II: dibagi menjadi dua fokus yaitu satu penari di panggung bagian kanan depan sebagai

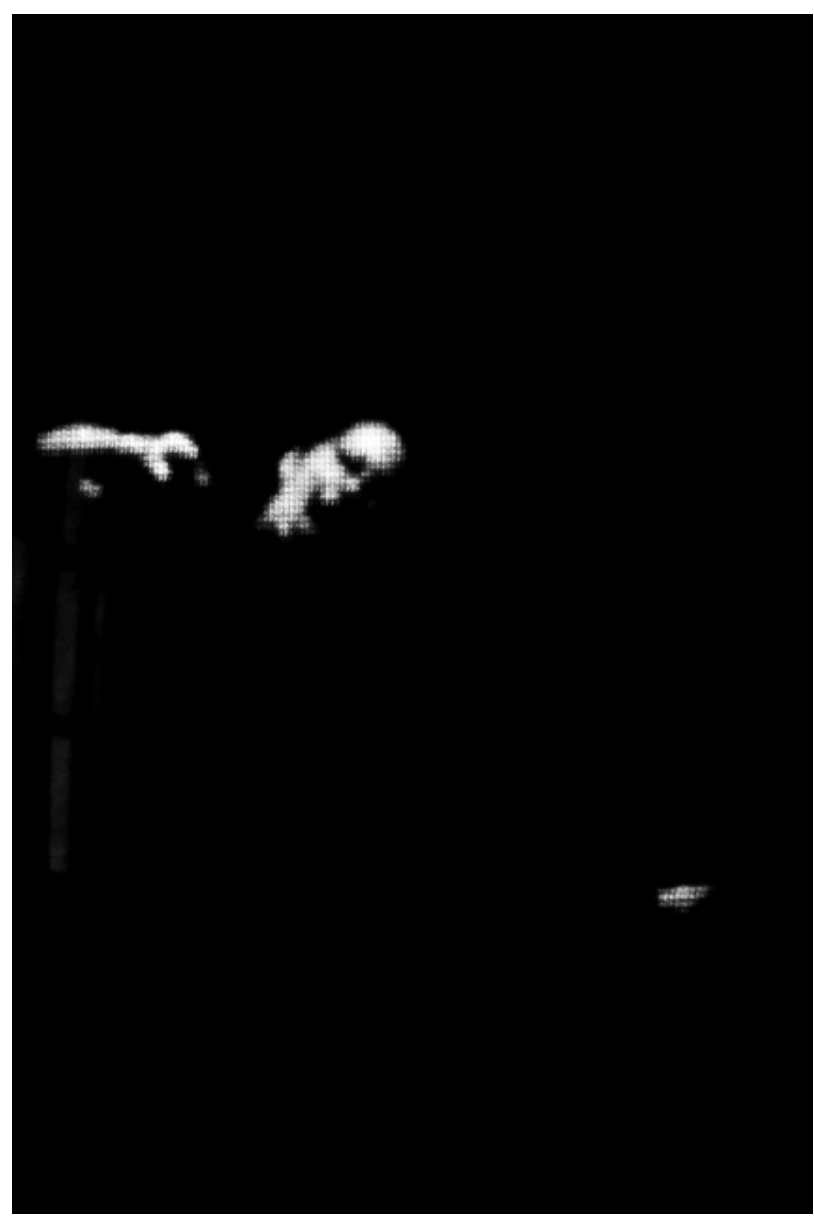

Gambar 3. Seorang penari sebagai simbol dosa. (Dokumentasi: DVD pementasan Kyrie Eleison)

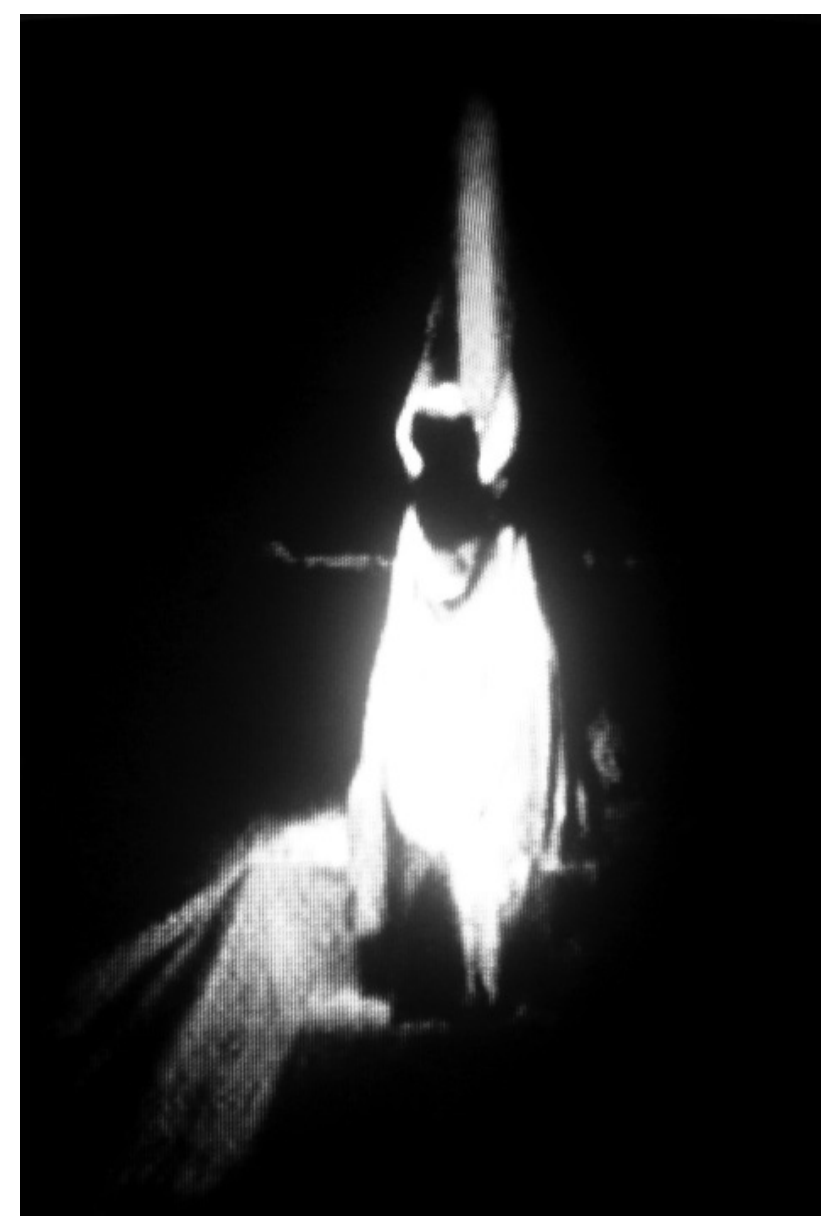

Gambar 4. Dua orang penari sebagai simbol doa, dengan simbol kain yang membumbung ke atas. (Dokumentasi: DVD pementasan Kyrie Eleison) 


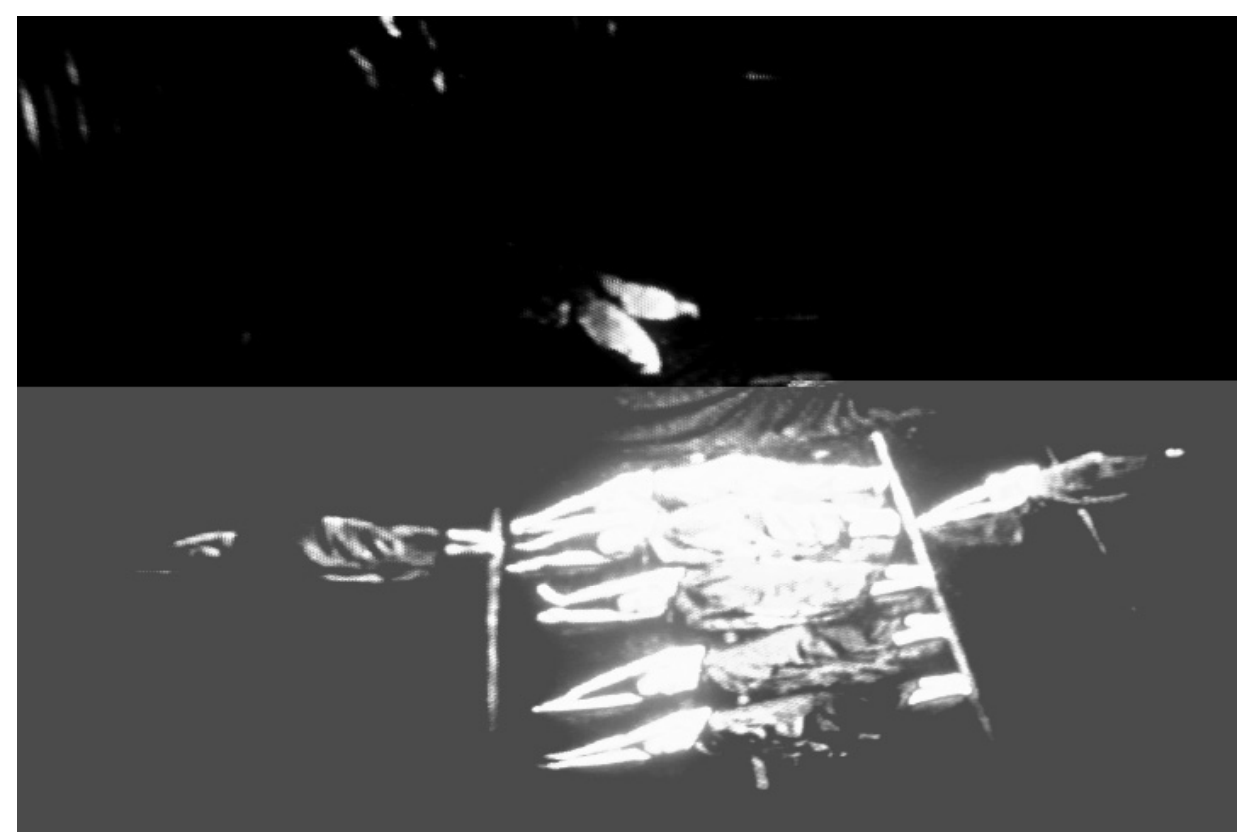

Gambar 5. Tampak pola lantai salib dalam level bawah. (Dokumentasi: DVD pementasan Kyrie Eleison)

simbol dosa, dan dua penari di panggung bagian kiri belakang sebagai simbol doa manusia.

Adegan III : penari masuk dari empat arah dan berpotongan pada satu titik pada pusat panggung sehingga membentuk pola lantai Salib $(+)$.

Pola lantai pada gambar di atas sekaligus menjadi representasi dari Yesus Jatuh Pertama Kalinya atau Perhentian III. Pola ini memang tidak begitu jauh berbeda dengan penggambaran Yesus jatuh saat memanggul Salib.

Adegan IV: penari menggambarkan duka mendalam dengan simbol-simbol dari perhentianperhentian dalam devosi Jalan Salib dan kisahkisah yang ada dalam kisah sengsara Yesus menuju penyaliban.

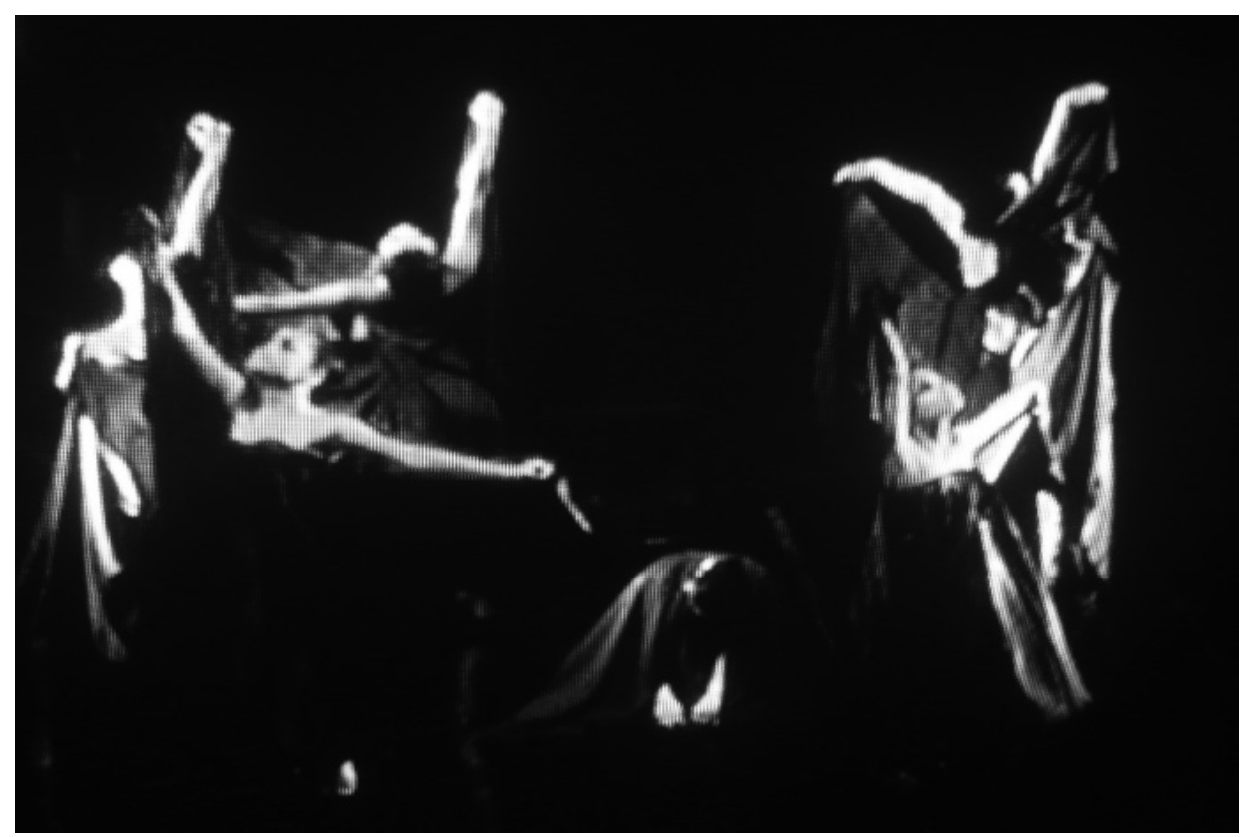

Gambar 6. Salah satu adegan yang melambangkan Yesus disiksa; seorang penari yang menunduk sebagai gambaran Yesus dan penari lainnya bergerak rampak mengelilinginya dengan meng-eksplore kostum hitam, (Dokumentasi: DVD pementasan Kyrie Eleison) 


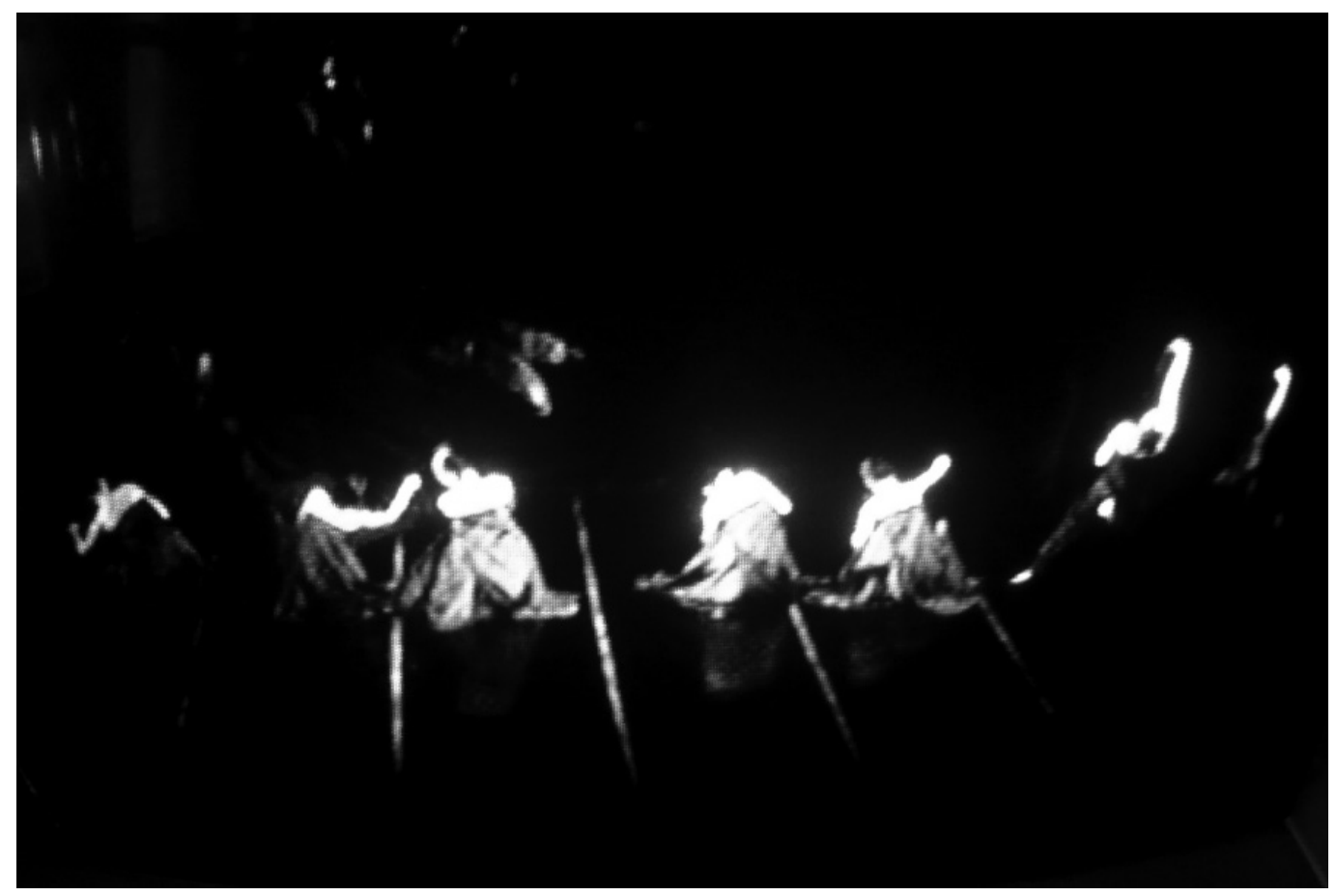

Gambar 7. Gerak improvisasi sebagai transisi pelepasan kostum hitam berganti putih. (Dokumentasi: DVD pementasan Kyrie Eleison)

Adegan V: penari melepas kostum luar yang berwarna hitam dan transisi menuju ke perubahan kostum putih. Hal ini sebagai simbol dari usaha penyelamatan Yesus bagi umat manusia dari segala dosa dengan rela wafat di kayu Salib, sehingga sengsara-Nya adalah kisah paling dramatik yang memberikan perubahan nyata bagi umat di dunia.
Adegan VI: penari yang telah berkostum putih terikat dengan kain putih sebagai simbol manusia selalu terikat oleh wahyu Tuhan. Kostum dan gerak ekspresif disimbolkan dengan sebuah perubahan yang indah bagi umat manusia di dunia berkat Yesus yang rela wafat di kayu Salib demi penebusan yang mulia.

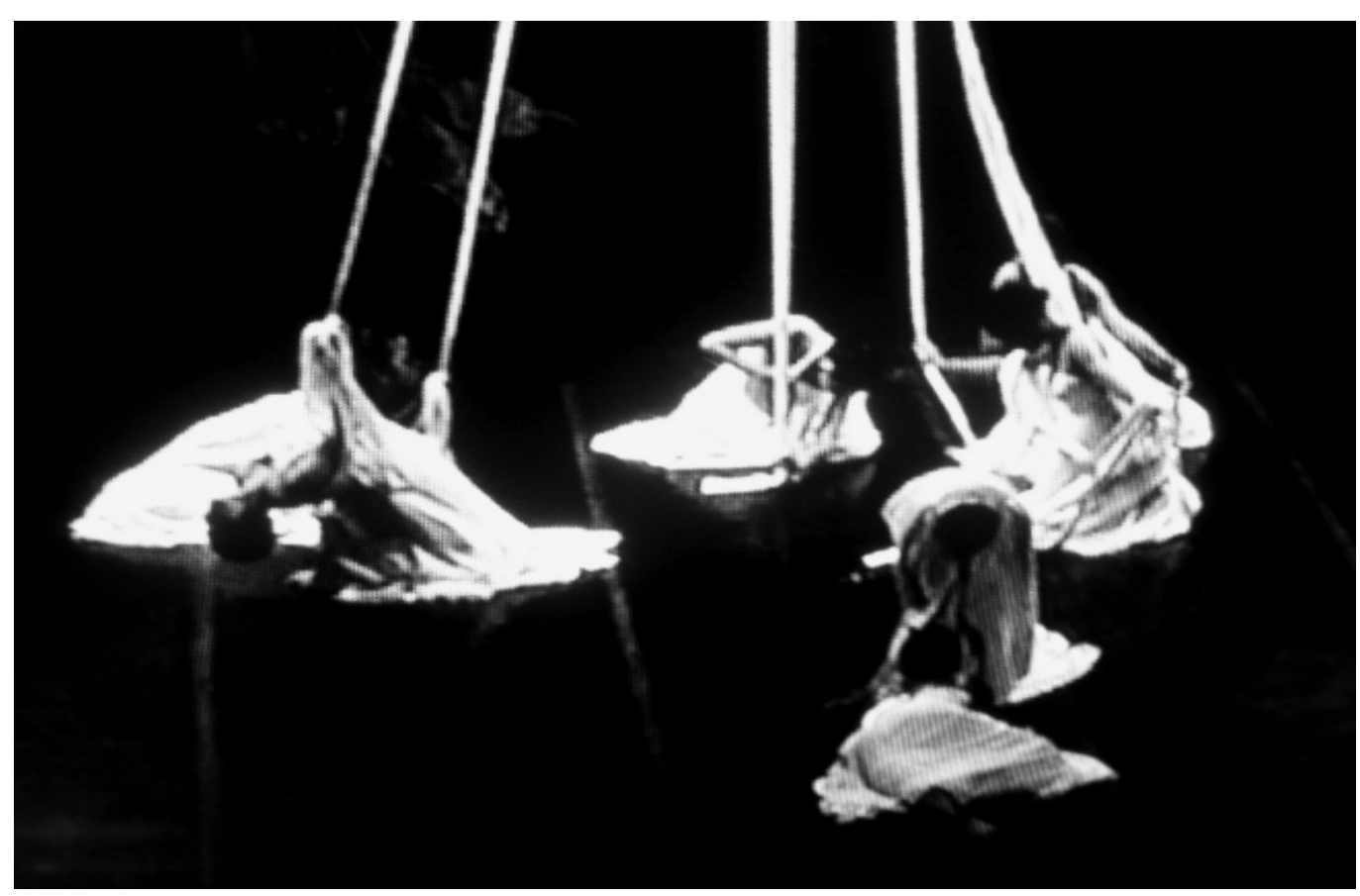

Gambar 8. Gerak eksplorasi kain putih yang diturunkan sebagai simbol turunnya wahyu Tuhan; tampak dua penari menggambarkan Bunda Maria menolong Yesus. (Dokumentasi: DVD pementasan Kyrie Eleison) 
Pada perhentian IV disebutkan bahwa Yesus bertemu dengan ibu-Nya. Dalam film Passion of The Christ, penggambaran pertemuan ini adalah ketika Bunda Maria yang begitu berduka atas sengsara putra-Nya berlari menolong Yesus ketika Yesus terjatuh. Sebelumnya Bunda Maria hanya mengikuti perjalanan Yesus menuju Bukit Golgota dengan berlinang air mata.

Enam adegan tersebut disajikan untuk mewakili kisah sengsara perjalanan Yesus yang terdapat pada kelima belas perhentian devosi Jalan Salib sehingga dapat tersampaikan maksud dan tujuan yang ingin disampaikan koreografer secara singkat dan jelas namun tetap menarik untuk ditonton sebagai suatu bentuk seni pertunjukan.

\section{Penutup}

Dalam memahami makna suatu karya seni dibutuhkan adanya interpretasi. Penelitian ini menganalisis simbol-simbol yang terdapat pada karya tari Kyrie Eleison. Tidak hanya sekedar mengkritik segala kekurangan yang ada pada karya tari, dan memberikan komentar pada penampilan penari, pemusik, atau tata artistiknya, akan tetapi ada banyak hal yang menjadi bahan pertimbangan terutama sebagai landasan (teori) dalam menginterpretasi Kyrie Eleison dan konteksnya. Dengan landasan teoretis hermeneutika, ditemukan berbagai pemaknaan simbol dalam teks Kyrie Eleison.

Dilihat dari elemen-elemen koreografinya, tema, gerak, musik, penari, pola lantai, tata rias busana, dan segala tata artistiknya, telah tampak bahwa Kyrie Eleison dekat dengan suatu tradisi liturgi Kristiani atau bersifat Gerejawi. Menginterpretasi bagian per bagiannya tidaklah sesederhana melihat nuansa Gereja pada saat pertunjukan berlangsung. Sebelum menginterpretasi, terlebih dahulu perlu memahami latar belakang ceritanya. Apa itu Jalan Salib, apa itu devosi, bagaimana relevansinya terhadap Al Kitab yang tentunya menjadi sumber yang mendasar. Seyogyanya mengerti dan memahami sebelum memberikan pemaknaan atas simbol-simbol yang tersaji dalam pertunjukan. Mengenai relevansi antara interpretasi Anna Wahyu Prasetyowati terhadap Jalan Salib dengan bagaimana ia menuangkannya dalam bentuk pertunjukan, tidak dapat dinilai dengan kata tepat ataupun tidak. Selama proses pengejawantahan dari pemikiran kemudian dituangkan dalam bentuk pertunjukan, tentunya telah mengalamai perkembangan dan penyesuaian faktor-faktor estesis penyajian sebuah karya dengan ideologi yang dimiliki pribadi koreografer.

Berdasarkan respons yang diberikan penonton pada akhir pertunjukan, nampaknya Kyrie Eleison merupakan suatu karya yang dapat memberi kesan tersendiri pada setiap orang yang melihat pertunjukannya. Elemen-elemen koreografinya memberikan kesan bahwa karya ini tidak sekedar memberikan hiburan yang semata-mata kosong, namun di dalamnya terdapat makna yang mendalam yang patut ditelaah. Kisah perjalanan Yesus Kristus dalam mengajarkan Firman Bapa-Nya, dengan penuh sengsara hingga akhir hidup-Nya wafat terpaku di kayu Salib merupakan nilai religius yang menjadi teladan bagi umat manusia dalam menjalankan perintah Tuhan. Kyrie Eleison juga mengandung nilai-nilai kemanusiaan bahwa setiap umat manusia mengalami sengsara, derita, dan kematian yang memang benar ada. Manusia harus mampu tabah dan tegar dalam menghadapi setiap ujian dan cobaan yang datang dari Tuhan, bila ingin mencapai kesadaran batiniah tertinggi serta memahami kebenaran Illahiah.

\section{Kepustakaan}

Ahimsa-Putra, Heddy Shri. 2000. Ketika Orang Jawa Nyeni. Yogyakarta: Galang Printika.

Dadijono, Darmawan. 2008. "Komposisi Tari Bunga Di Atas Karang" dalam Resital Jurnal Ilmiah Seni Pertunjukan, Vol. 9. No. 2.

Doubler, Margaret N.H'. 1985. Tari Pengalaman Seni yang Kreatif, terj. Tugas Kumorohadi. Surabaya: Sekolah Tinggi Kesenian Wilwatika.

Gie, The Liang. 1997. Filsafat Keindahan. Yogyakarta: PUBIB.

Hadi, Y. Sumandiyo. 2003. Aspek-aspek Dasar Koreografi Kelompok, Yogyakarta: Manthili.

Hawkins, Alma M. 2003. Mencipta Lewat Tari. terj. Y. Sumandiyo Hadi. Yogyakarta: Manthili.

Injil, Al Kitab. 2002. Jakarta: Lembaga Al Kitab Indonesia.

Kusmayati, A.M. Hermin, 1990, "Makna Tari Dalam Upacara di Indonesia", dalam Pidato Ilmiah Dies Natalis ISI Yogyakarta, 21 Juli, Yogyakarta: ISI Yogyakarta 
Lutan, Deddy. 2008. "Benarkah Ada Ilmu Penciptaan Karya Tari?", makalah dalam Seminar Nasional Menuju Pencerahan Estetika Seni Pertunjukan, Fakultas Seni Pertunjukan Institut Seni Indonesia Yogyakarta.

Prasetyowati, Anna Wahyu. 2009. “Kyrie Eleison II”. [Skripsi]. Yogyakarta: Jurusan Tari, Fakultas Seni Pertunjukan, Institut Seni Indonesia Yogyakarta.

Saidi, Acep Iwan. 2008. "Hermeneutika, Sebuah Cara Untuk Memahami Teks", dalam Jurnal Sosioteknologi, Edisi 13.

Sembiring, P. Emmanuel J, 2007, “Liturgi. Sumber dan Puncak Kehidupan", dalam Majalah Liturgi, vol. 18 November-Desember.

Smith, Jacqueline, 1987, Komposisi Tari: Sebuah Petunjuk Praktis Bagi Guru, terj. Ben Suharto, Yogyakarta: Ikalasti.

Suharso dan Ana Retnoningsih. 2005. Kamus Besar Bahasa Indonesia. Semarang: Widya Karya.
Turner, Margery, J, 2007, Newdance: Pendekatan Koreografi Nonliteral, terj. Y. Sumandiyo Hadi, Yogyakarta: Manthili.

Widyasmoro, Frideswinda R. 2004. "Pertunjukan Tari di Dalam Gereja Katolik Studi Kasus Sendratari Kelahiran dan Kebangkitan Isa Almasih Karya Bagong Kussudiarjo", [Skripsi]. Yogyakarta: Jurusan Tari, Fakultas Seni Pertunjukan, Institut Seni Indonesia Yogyakarta.

\section{Sumber Audio/Video}

Prasetyowati, Anna Wahyu. 2009. Kyrie Eleison (DVD), koleksi pribadi.

\section{Informan}

Anna Wahyu Prasetyowati, 23 tahun, koreografer Kyrie Eleison.

Antonius, 50 tahun, rohaniwan Katolik. 